\title{
Metabolite Activity of Endophy Fungi Isolated from Betle Leaf (Piper betle) Against Candida Albicans
}

\author{
Aini $^{1 *}$, Edi Kurniawan ${ }^{1}$, Sumiatun ${ }^{1}$ \\ ${ }^{1}$ D3Medical Laboratory Technology, Politeknik Medica Farma Husada Mataram, Indonesia
}

\author{
Article History \\ Received : December $15^{\text {th }}, 2021$ \\ Revised : December $31^{\text {th }}, 2021$ \\ Accepted : January $10^{\text {th }}, 2022$ \\ Published : January $21^{\text {th }}, 2022$ \\ *corresponding author: \\ Aini, \\ Politeknik Medica Farma \\ Husada Mataram, \\ Indonesia \\ Email: ainie.mfh@gmail.com
}

\begin{abstract}
Betle (Piper betle) is a type of plant producing antimicrobial substances and secondary metabolites that are potentially used for the production of new drugs. Candidiasis is a disease caused by Candida albicans and causes diseases of the mucosa of the mouth, digestive tract, and vagina. The study aimed to isolate the betle leaf endophyte fungus (Piper betle L.) and find out the activity of its metabolites against Candida albicans. The research was conducted at the Laboratory of Plant Physiology and Biotechnology, Faculty of Agriculture, University of Mataram. The research method used was descriptive observation. The purpose of this study was to isolate endophytic fungi and their activity against Candida albicans from beetle leaves. The yield of endophytic fungal secondary metabolites was obtained by fermentation method, and the activity of Candida albicans was detected by diffusion method. Isolation test obtained from R\&D hospital NTB Province. The research results obtained the endophytic fungi isolated from beetle leaves (Piper betle L.) and obtained the identification results of the fungus Cephalosporium.
\end{abstract}

Keywords: Betle Leaf (Piper betle L.), Candida albicans, Fungal Endophyte

\section{Pendahuluan}

Organisasi Kesehatan Dunia (WHO) (2012) merekomendasikan agar negara-negara di dunia memanfaatkan obat tradisional di bidang kesehatan. Tumbuhan di alam memiliki khasiat obat untuk pengobatan penyakit menular yang disebabkan oleh mikroorganisme. Tumbuhan merupakan bahan kimia yang memiliki banyak manfaat sebagai obat antijamur, seperti pemanfaatan buah pinang (Piper betle) (Katili, 2015). Piper betle adalah sejenis liana. Pinang (Piper betle Linn.) termasuk dalam keluarga lada, dan tradisi makan pinang yang begitu terkenal di dalam kehidupan dari masyarakat Indonesia. Buah pinang bermanfaat guna menghilangkan bau mulut dan juga bau badan, serta demi kesehatan gigi dan, tidak hanya itu juga berguna untuk berbagai penyakit, sebagai misalnya ialah bisul, gatal-gatal, mimisan, sariawan, kumur, keputihan untuk wanita dan lain sebagainya. Daun dari Buah pinang ini mempunyai aroma yang khas, dengan kandungan minyak atsiri sebesar 4,2\% (Iptika A, 2014). Di dalam tanaman sirih ini terdapat berbagai bagian tertentu, di iantaranya ialah daun, akar dan biji yang memiliki potensi guna mengobati, namun biasanya yang acapkali dimanfaatkan ialah bagian daun. Bagian yang acapkali dipergunakan untuk proses pengobatan ini ialah bagian daun, di dalam berbagai penelitian yang dilaksanakan Saraswati (2011) mengungkapkan bahwa daun sirih ini sendiri memiliki fungsi antibakteri karena memiliki beberapa kandungan (Ibrahim, 2013) bahkan dengan rebusan daun sirih ini mampu menyebabkan patologis keputihan terhadap remaja ini turun (Zahid Fikri dan Nur Ismi, 2015).

Jamur endofit ini didefinisikan sebagai jamur yang bertumbuh dan berkoloni pada inang atau jaringan tumbuhan, khususnya pada bagian daun, akar dan juga batang. Jamur endofit ini juga mampu menghasilkan metabolit sekunder yang sama dengan inangnya tersebut serta senyawa bioaktifnya. Hal ini dikarenakan bahwa jamur endofit ini mengalami proses dari koevolusi transfer genetik atas inang yang ada ini. Kemampuan dari mikroba endofit yang terdapat di dalamnya ini akan dapat menghasilkan suatu senyawa bioaktif yang sebagai hal yang berpotensial untuk diperkembangkan untuk dijadikan obat herbal 
nantinya. Hal ini disebabkan bahwa mikroba endofit ini didefinisikan sebagai mikroorganisme dapat diperkembangbiakan dengan mudah, mempunyai siklus hidup yang singkat serta mampu menghasilkan senyawa bioaktif yang jumlahnya besar dengan cara metode fermentasi yang dilaksanakannya (Noverita, 2009).

Candida albicans ini didefinisikan sebagai suatu flora normal yang berkembang dan hidup di dalam mukosa mulut, vagina dan juga saluran pencernaan (Sardi, et al 2013). Sebagai flora normal, Candida tidak menular, tetapi jika ada gangguan kekebalan atau disfungsi kekebalan, baik sendiri atau disebabkan oleh penyakit lain. Infeksi vagina dan kandidiasis oral yang diprediksikan berlangsung dengan jumlahnya sekitar 40 juta infeksi per tahun (Naglik et al.2014). Penggunaan obat antijamur berbahan kimia seperti amfoterisin B, nistatin, ketokonazol, fukonazol, dan griseofulvin sering menimbulkan efek samping yang berat dan resistensi terhadap kandidiasis (Katzung, 2011). Hal ini dikarenakan bahwa efek samping yang dihasilkan atas penggunaan dari obat-obatan kimia yang sebelumnya dilaksanakan, maka banyak terapi alternatif yang menggunakan bahan-bahan alami sebagai antibakteri karena rendahnya efek samping dari bahan-bahan alami tersebut (Moeljanto, 2003).

Penelitian Nurul (2010) menyatakan bahwa penggunaan dari ekstrak daun sirih (Piper betleL.) yang mana bahwa konsentrasiinya ini ialah $80 \%$ dan $100 \%$ terbukti dapat memberikan pengaruh terhadap pertumbuhan dan juga perkembangan dari Candida albicans. Mengacu pada uraian pernyataan yang dikemukakan Barik et al (2010) menjelaskan bahwa jamur endofit yang tinggal dan hidup di dalam jarungan tumbuhan yang sehat ini juga dapat menghasilkan metabolit bioaktif yang sama atau derivatifnya tersebut dapat menjadi aktif dibandingkan dengan yang dihasilkan tumbuhan inang. Kemampuan dari mikroba endofit ini dalam memproduksi senyawa bioaktif ini ialah sebagai hal yang berpotensial guna nantinya diperkembangkan untuk menjadi suatu obat herbal. Hal ini disebabkan bahwa mikroba endofit ini ialah sebagai mikroorganisme yang dapat diperkembangbiakan dengan mudah, mempunyai siklus hidup yang singkat serta mampu menghasilkan senyawa bioaktif yang jumlahnya besar dengan cara metode fermentasi yang dilaksanakannya (Vica, 2015).

Mengacu pada latar belakarang yang diuraikan tersebut di atas, dengan ini perlu untuk dilaksanakan penelitian untuk pengujian dari aktivitas metabolit Jamur Endofit yang dapat diisolasikan oleh Daun Sirih (Piper betle) pada jamur Candida albicans, hal ini dikarenakan bahwa jamur endofit yang mengacu pada penelitian literatur ini berpotensial untuk nantinya menghasilkan metabolit sekunder (Tan and Zou, 2001 dalam Sugijanto, et al., 2004). Kebaruan dari penelitian ini adalah potensi mikroba endofit dari daun sirih dapat dimanfaatkan sebagai anfifungi tanpa memanfaatkan daun sirih secara langsung. Beberapa peneliti sebelumnya telah melakukan isolasi terhadap mikroba endofit akan tetapi belumkhususdiujikan terhadap candida albicans.

\section{Bahan dan Metode}

\section{Desain Penelitian}

Untuk penelitian ini, desain penelitian yang dilaksanakan ialah berupa penelitian Observasi deskriptif yang dilakukan dengan cara melaksanakan isolasi untuk jamur endofit dari daun sirih (Piper betle L.), yang nantinya akan diidentifikasi dan dilakukan dengan menguji aktivitas metabolit jamur endofit pada Candida albicans(Gemsih et. al 2017).

\section{Tempat dan Waktu}

Untuk penelitian ini dilangsungkan pada Laboratorium Fisiologi dan Bioteknologi Tanaman, Fakultas Pertanian, Universitas Mataram dan berlangsung di bulan Mei 2019.

\section{Variabel dan Definisi Operasional}

Untuk penelitian yang dilaksanakan ini ialah dengan menggunakan beberapa variabel penelitian, di antaranya ialah variabel independen dalam penelitian ini ialah berupa jamur endofit daun sirih (Piper betleL.), sementara itu untuk variabel depennya penelitian ini ialah Candida albicans. Definisi operasional dalam penelitian ini meliputi Sirih (Piper betle), Jamur endofit, Candida albicans, Jamur endofit daun sirih (Piper betle L.) dan juga Uji aktivitas metabolit sekunder.

\section{Populasi dan Sampel}

Populasi penelitian ini didefinisikan sebagai subjek ataupun objek yang memiliki ciri khas tersendiri dan juga mutu tertentu, yang peneliti tetapkan guna nantinya dipelajari dan dihasilkan penarikan kesimpulan (Sugiyono, 2011). Untuk penelitian ini, populasi penelitian ini ialah berupa pohon sirih (betle). Sampel 
penelitian didefinisikan sebagai jumlah ataupun bagian serta karakteristik tertentu yang ada pada populasi penelitian itu sendiri (Sugiyono, 2011). Sampel penelitian fyang diambil yaitu daun dari tanaman sirih (Piper betleL.).Alasan penggunaan sampel daun sirih dari Desa Bonjeruk, Kecamatan Jonggat, Kab.Lombok Tengah dikarenakan habitat tanamannya lembab sehingga mempengaruhi khasiat yang dihasilkan daun sirih.

\section{Teknik Pengumpulan Data}

\section{Identifikasi jamur endofit dari isolasi daun sirih (Piper betle $\mathbf{L}$.)}

Jamur endofit diisolasi dari daun sirih (Piper betleL.). Daun sirih dipotong sepanjang \pm $2 \mathrm{~cm}$ dicuci dengan air mengalir selama 5 menit. Setelah pencucian, dilakukan sterilisasi permukaan dengan memasukan ke dalam larutan alcohol 70 selama 5 menit, dilanjutkan ke dalam larutan $\mathrm{NaOCl} 1$ selama 5 menit kemudian dikeringkan dengan tissue steril. Potongan daun sirih (Piper betleL.) yang sudah steril ditanam ke dalam cawan petri yang berisi media PDAC. Pengamatan dilakukan setiap hari sampai tampak jamur yang tumbuh kemudian jamur endofit yang tumbuh diisolasi dan dimurnikan pada media PDAC yang baru (Indriana, 2005). Setiap koloni yang berbeda bentuk maupun warnanya disubkultur lagi pada medium PDAC baru (Hidayati, 2010). Jamur endofit yang telah diinkubasi kemudian diidentifikasi berdasarkan ciri makroskopis dan ciri-ciri mikroskopisnya. Pengamatan ciri makroskopis dilakukan dengan cara melihat langsung bentuk dan warna koloni jamur endofit sedangkan secara ciri mikroskopis melakukan pengamatan morfologi dengan menggunakan mikroskop.

\section{Prosedur pengujian jamur endofit terhadap jamur Candida albicans}

Fermentasi organisme endofit ini dilaksanakan dengan mempergunakan media PDB (Potato Dextrose Broth), yang tujuannya ialah agar dapat menghasilkan ekstrak yang di dalamnya memiliki kandungan senyawa metabolit sekunder yang berasal dari isolat parasites endofit. Koloni murni parasites endofit yang sudah melaksanakan sporulasi dalam media PDA ini nantinya akan dipotong dan kemudian diambil tiga potongan yang ukurannya $\pm 1 \times 1$ $\mathrm{cm}$. Potongan parasites tersebut kemudian diinokulasikan ke dalam media fermentasi cair PDB sebanyak $500 \mathrm{~mL}$. Labu erlenmeyer yang berisi media fermentasi cair PDB dan potongan kultur parasites endofit difermentasi goyang menggunakan rotational shaker dengan kecepatan $140 \mathrm{rpm}$ (kocokan/menit), dilakukan pada suhu ruang $\left(27^{\circ} \mathrm{C}\right)$ selama 14 hari (Sinaga et al., 2009; Rollando, 2016).Untuk menguji aktivitas metabolit sekunder dari jamur endofit terhadap pertumbuhan jamur Candida albicans dilakukan dengan menggunakan metode sumuran pada media PDA (Potato Dextrose Agar) dengan mengambil hasil fermentasi sebanyak $50 \mu \mathrm{l}$ (Vilca,2015).

\section{Hasil dan Pembahasan}

\section{Pertumbuhan koloni jamur endofit daun sirih (Piper betle L.) hasil isolat pada medium PDAC.}

Setelah dilakukan isolasi terhadap fungi endofit yang tumbuh berdasarkan jaringan daun sirih (Piper betleL.) dalam medium PDAC selama lima hari dihasilkan isolat fungi endofit menggunakan rona koloni yg sama. Gambar output isolasi fungi endofit berdasarkan daun sirih (Piper betle L.) dalam medium PDAC bisa dicermati dalam gambar berikut.

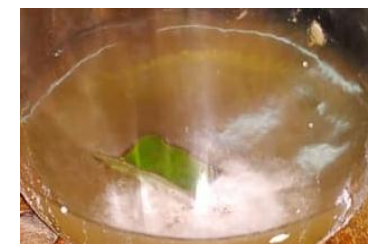

Gambar 1. Hasil isolasi jamur endofit daun sirih (Piper betleL.) pada medium PDAC selama 5 hari

Berdasarkan pada hasil dari pengamatan makroskopis pada penampakan koloni isolat jamur endofit ini dapat ditemukan bahwasannya dalam isolat ini menunjukkan bentuk dan warna koloni yang sama yang diambil dari sampel yang sama. Sesudah dilaksanakan pemurnian dengan berlandaskan bentuk dan juga warna yang ada dalam media PDAC baru secara makroskopis, dengan demikian dihasilkan bahwa hasil isolat dengan warna koloni yang sama

\section{Hasil identifikasi isolat jamur endofit daun sirih (Piper betleL.) pada medium PDAC \\ Mengacu pada hasil pengamatan yang dilaksanakan, jamur endofit yang sudah dimurnikan dan juga diisolasikan dengan menggunakan daun sirih (Piper betle L.), dengan ini dapat dilaksanakan identifikasi bahwa dengan meninjau terhadap ciri khas dari mikroskopis dan juga makroskopis, dengan merujuk terhadap}


buku petunjuk klasifikasi (Barnet, 1972). Pada medium PDAC koloni jamur ini memiliki warna putih dan bersih, pertumbuhan koloni datar, miselium menyebar, dan juga tipis mirip beludru kasar. Tumbuh pada suhu ruangan, mulai tumbuh pada medium PDAC pada hari kelima. Pengamatan dilakukan di bawah mikroskop binokuler perbesaran 10x40, tampak miselium bercabang, hifa aseptat dan hyaline sedangkan konidiofor pendek, hyaline, aseptat dan inclining. Hasil pengamatan makroskopis ini mencangkup dengan pola penyebaran, tekstur koloni, bentuk koloni dan juga warna koloni, sementara itu dalam pengamatan mikroskopis mencangkup dengan struktur hifa, baik itu yang tidak bersekat ataupun yang bersekat, konidia dan spora, disajikan pada Tabel 1.
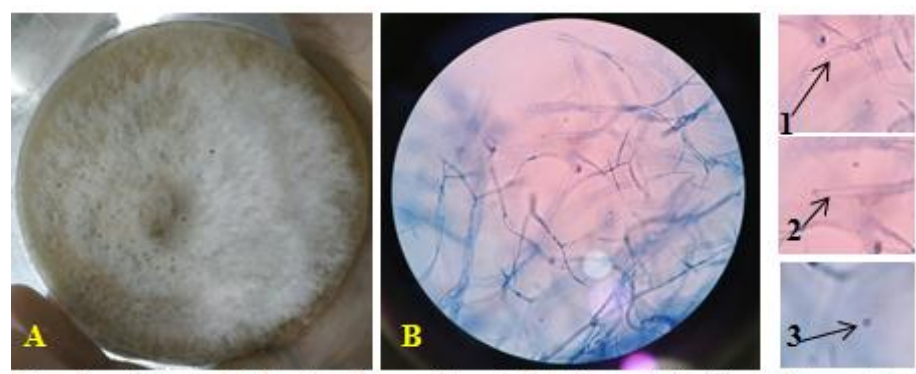

Gambar 4.2. A. Koloni pada medium PDAC setelah 4 hari dimumikan.

B. Mikroskopis jamur endofit pada perbesaran 10X40.

C. Morfologi jamur endofit (ket: 1. hifa, 2. konidia,

3. konidiofor)

Tabel 1. Pengamatan Makroskopis dan Mikroskopis Jamur Endofit

\begin{tabular}{|c|c|c|c|c|c|c|c|c|}
\hline \multirow{3}{*}{$\begin{array}{l}\text { Kode } \\
\text { isolat }\end{array}$} & \multirow{2}{*}{\multicolumn{4}{|c|}{$\begin{array}{c}\text { Makroskopis } \\
\text { Koloni }\end{array}$}} & \multicolumn{3}{|c|}{ Mikroskopis } & \multirow{3}{*}{$\begin{array}{c}\text { Jenis jamur } \\
\text { endofit }\end{array}$} \\
\hline & & & & & \multirow[b]{2}{*}{ Hifa } & \multirow[b]{2}{*}{ Konidia } & \multirow[b]{2}{*}{ Konidiofor } & \\
\hline & Warna & Bentuk & Tekstur & $\begin{array}{c}\text { Pola } \\
\text { penyebaran }\end{array}$ & & & & \\
\hline $\mathrm{J}_{1}$ & $\begin{array}{l}\text { Putih } \\
\text { bersih }\end{array}$ & Bulat & Kasar & Beludru & $\begin{array}{c}\text { Tidak } \\
\text { bersekat }\end{array}$ & Pendek & Ramping & $\begin{array}{l}\text { Cephalospo } \\
\text { rium sp. }\end{array}$ \\
\hline
\end{tabular}

Berdasarkan hasil pengamatan secara makroskopis dan mikroskopis dari jamur endofit daun sirih (Piper betleL.) pada tabel di atas diketahui memiliki ciri makroskopis koloni jamur, di antaranya ialah warna putih dan bersih, pertumbuhan koloni datar, miselium menyebar, dan juga tipis mirip beludru kasar. Sedangkan pengamatan secara mikroskopis dengan perbesaran 10x40 di bawah mikroskop, pada hari kelima setelah inokulasi tampak miselium bercabang, hifa aseptat (tidak bersekat) dan hyaline (transparan) sedangkan konidiofor berbentuk pendek, hyaline, aseptat dan inclining serta konidia terdiri dari 1 sel. Berdasarkan ciri tersebut diketahui bahwa jamur endofit yang ditemukan adalah jamur endofit dari variety Cephalosporium sp yang termasuk dalam family Moniliaceae. Hal ini sesuai dengan Miftachul (2008) yang mengungkapkan bahwasannya jamur Cephalosporium sp ini mempunyai berbagai karakteristik, di antaranya ialah miselium bercabang, hifa aseptat dan hyaline sedangkan konidiofor pendek, hyaline, aseptat dan inclining serta konidia hyaline dan 1 sel. Selain itu juga menurut Barnet dan Hunter (1972) jamur Cephalosporium sp memiliki bentuk konidiofor dan fialid yang sloping atau sedikit membengkak. Konidia berwarna transparan dan konidia terdiri dari 1 sel.

Adanya aktivitas antifungi terhadap Candida albicans disebabkan karena jamur endofit yang ditemukan dalam penelitian ini (Tabel 1) adalah jamur Cephalosporium sp. Menurut Suwandi (1989) jamur genus Cephalosporium $s p$ mampu menghasilkan antibiotik sefalosporin. Selain itu juga, pada hasil penelitian Abdollah (2008) bahwa identifikasi dan juga isolasi untuk jamur endofit yang terdapat dalam daun Mimba (Azadirachta indica A. Juss) yang berfungsi sebagai penghasil senyawa antifungi pada jamur Aspergillus niger dan juga Candida albicans ini ditemukan dalam jamur Cephalosporium $s p$ yang dapat mengakibatkan pertumbuhan Candida albicans dengan diameter zona hambat sebesar 4,3 mm ini menjadi terhambat. Abdollah (2008) menyatakan 
bahwa isolat jamur endofit dari daun Mimba ini dapat menyebabkan terhambatnya pertumbuhan dari jamur Candida albicans dan Aspergillus niger, dengan ini dapat dinyatakan akan dapat memproduksikan metabolit sekunder yang fungsinya ialah sebagai antifungi. Ditemukannya perbedaan pada besarnya zona hambat yang terbentuk ini mungkin diakibatkan dengan terdapatnya metabolit sekunder yang berbeda yang dihasilkan jamur endofit pada daun sirih (Piper betleL.). Daun Mimba ini memiliki kandungan yang terdirikan atas berbagai komponen atas produksi metabolit sekunder, yang di antaranya ialah nimbidin, nimbin, meliantriol, salanin, dan juga azadirachtin (Kardinan, 2003) sedangkan jamur endofit daun sirih memiliki beberapa kandungan senyawa metabolit sekunder berupa Penicilin, sefalosporin, fumigasin, javanisin dan chetomin (Suwandi, 1989).

$$
\text { Menurut Miftachul }
$$

mengungkapkan bahwa dalam pengamatan makroskopis pada penampakan koloni isolat jamur endofit daun sirih (Flautist betleL.) ini menunjukkan penampakan yang tidak sama, walaupun diambil pada sampel daun sirih yang sama jenisnya dan diambil dari daerah yang berbeda serta didapatkan sembilan isolat jamur endofit yang dua diantaranya termasuk dalam class Cephalosporium sp. Hal ini selaras dengan yang dinyatakan Atmosukarto (2006) yang mengungkapkan bahwa tanaman antara satu dengan yang lainnya tentu memiliki perbedakaan, dengan demikian biotop untuk tempat hidup mikroba ini sifatnya sangat unik. Lebih lanjut, bahwa fisiologi tumbuhan yang tinggi ini mencangkup pada spesies yang sama akan tetapi lingkungannya tersebut berbeda.

\section{Hasil uji aktivitas metabolit jamur endofit daun sirih (Piper betle L.) terhadap Candida albicans}

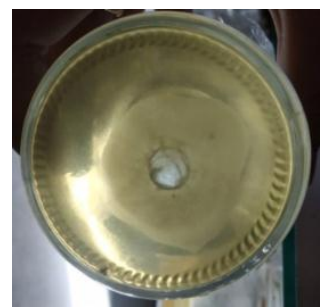

Gambar 3. Hasil uji aktivitas metabolit jamur endofit daun sirih terhadap Candida albicans

Hasil uji aktivitas metabolit jamur endofit daun sirih (Piper betle L.) memperlihatkan bahwa isolat dapat menghambat pertumbuhan dari jamur Candida albicans dengan diameter zona hambat yaitu mencapai $30,9 \mathrm{~mm}$. penelitian lain yang dilaakukan oleh isolasi jamur Endofit dari Daun Sirih (Piper betle) terhadap jamur $C$. albicans ini menunjukkan zona hambat yang senilai $1,96 \mathrm{~mm}$ atas isolate yang tidak sama ini tidak mampu menyebabkan pertumbuhan jamur Candida albicans ini menjadi terhambat.

Tabel 2. Pengamatan uji aktivitas metabolit jamur endofit daun sirih

\begin{tabular}{|c|c|}
\hline Kode Isolat & $\begin{array}{c}\text { Interpretasi Daya } \\
\text { Hambat }\end{array}$ \\
\hline $\mathrm{J}_{1}$ & Menghambat $(30,9 \mathrm{~mm})$ \\
\hline Kontrol Positif $(+)$ & Menghambat $(50 \mathrm{~mm})$ \\
\hline
\end{tabular}

Berdasarkan table di atas hasil pengukuran diameter zona hambat pertumbuhan Candida albicans didapatkan diameter zona hambat sebesar $30,9 \mathrm{~mm}$, diameter zona hambat yang dihasilkan termasuk dalam kriteria kuat (National Commite Clinical Laboratory Standards, 2008). Berdasarkan hasil uji aktivitas metabolit jamur endofit daun sirih terhadap Candida albicans diketahui mampu menghambat pertumbuhan Candida albicans dengan diameter zona hambat sebesar 30,9 mm yang termasuk dalam kriteria kuat. Hal ini sesuai dengan kriteria kekuatan antifungi yang ditetapkan oleh NCCLS (2008) yang menyatakan bahwa kekuatan antifungi termasuk ke dalam kriteria kuat jika diameter sebesar $\geq 28 \mathrm{~mm}$, kriteria sedang jika diameter 21-27 $\mathrm{mm}$ dan kriteria lemah jika diameter $\leq 20 \mathrm{~mm}$. Hasil penelitian ini juga diperkuat oleh penelitian Miftachul (2008) yang mengatakan bahwa jamur endofit yang diisolasi dari daun sirih (Piper betleL.) memiliki aktivitas antifungi terhadap Candida albicans. Terdapat berbagai penelitian yang mengungkapkan bahwasannya daun sirih hijau (Piper betleL.) yang berbentuk minyak atsiri, infusum, perasan, rebusan, dan ekstrak etanol mempunyai efek antifungi terhadap Candida albicans (Soemiati dan Elya, 2002; Hertiani dan Indah, 2002; Nurrokhman, 2006; Ebtasari, 2007). Uraian ini juga diperkuat dengan pernyataan yang dikemukakan Tan dan Zou (2001) dalam Sugiyanto (2007) yang mengungkapkan bahwa jamur endofit ini nantinya akan dapat menghasilkan berbagai aktivitas tertentu, di antaranya ialah insektisida, hormon pertumbuhan 
yang ada dalam tanaman, antibakteri, antifungsi dan lain sebagainya.

Berdasarkan hasil uji aktivitas metabolit jamur endofit daun sirih terhadap Candida albicans diketahui mampu menghambat pertumbuhan Candida albicans dengan measurement zona hambat sebesar $30,9 \mathrm{~mm}$ yang termasuk dalam kriteria kuat. Hal ini sesuai dengan kriteria kekuatan antifungi yang ditetapkan oleh NCCLS (2008) yang menyatakan bahwa kekuatan antifungi termasuk ke dalam kriteria kuat jika measurement sebesar $\geq 28 \mathrm{~mm}$, kriteria sedang jika width 21-27 mm dan kriteria lemah jika breadth $\leq 20 \mathrm{~mm}$. Hasil penelitian ini juga diperkuat oleh penelitian Miftachul (2008) yang mengatakan bahwa jamur endofit yang diisolasi dari daun sirih (Piper betle L.) memiliki aktivitas antifungi terhadap Candida albicans. Berbagai hasil peneltiian yang mengungkapkan bahwa daun sirih hijau (Piper betle L.) yang berbentuk rebusan, ekstrak etanol, minyak atsiri, infusum, dan juga perasan ini mempunbyai efek antifungi yang terdapat dalam Candida albicans (Soemiati dan Elya, 2002; Hertiani dan Indah, 2002; Nurrokhman, 2006; Ebtasari, 2007). Ungkapan ini diperkuat dengan yang dinyatakan Ta dan Zou (2001) dalam Sugiyanto (2007) yang mengungkapkan bahwa jamur endofit ini nantinya akan dapat menghasilkan berbagai aktivitas tertentu, di antaranya ialah insektisida, hormon pertumbuhan yang ada dalam tanaman, antibakteri, antifungsi dan lain sebagainya.

Selain senyawa sepalosporin yang terkandung dalam daun sirih, jamur endofit daun sirih juga menghasilkan senyawa fenolik dan atau senyawa fenil propane (Nurul, 2010). Senyawa fenolik ini nantinya akan dapat mengakibatkan terjadinya denaturasi protein, yakni adanya struktur tersier protein yang menyusun pada dinding dari sel jamur yang mengalami kerusakan, dengan demikian nantinya akan menyebabkan fungsi protein yang ada pada dinding sel mikroorganisme ini mengalami kerusakan. Metabolit sekunder dari jamur endofit yang terdapat pada daun sirih (Piper betle L.) dapat dipengaruhi oleh faktor suhu tanaman sirih tersebut tumbuh, semakin lembab lingkungannya maka semakin bagus senyawa metabolit yang dihasilkan oleh tanaman sirih. Hal ini sejalan dengan hasil penelitian yang dilaksanakan Budiprakoso (2010) yang mengungkapkan bahwa jamur endofit yang melimpah ini disebabkan adanya faktor abiotik dan juga biotik. Faktor biotik ini sendiri terdirikan atas spresies dan juga varietas inang, sementara itu untuk faktor abiotik yang memberi pengaruh ini ialah beberapa faktor, di antaranya ialah teknik budidaya, kadar air tanah, kelembaban relative, suhu dan juga cuaca. Hal ini diperkuat dengan hasil penelitian yang dilaksanakan Barik, et al. (2010) yang mengungkapkan bahwa jamur endofit yang tinggal dan hidup di dalam jarungan tumbuhan yang sehat ini juga dapat menghasilkan metabolit bioaktif yang sama atau derivatifnya tersebut dapat menjadi aktif dibandingkan dengan yang dihasilkan tumbuhan inang.

\section{Kesimpulan}

Mengacu hasil penelitian yang sudah dilaksanakan, dengan ini didapatkan simpulan bahwa Jamur endofit ini berhasil diisolasi dari daun sirih (Piper betleL.) mengacu pada ciri dari mikroskopis dan juga makroskopis ini dihasilkan bahwa jenis jamur endofit dari genus Cephalosporium sp. Hasil uji aktivitas metabolit jamur endofit ini menunjukkan bahwa isolate ini mampu menyebabkan pertumbuhan Candida albicans ini menjadi terhambat dengan breadth zona hambat $30,9 \mathrm{~mm}$ termasuk dalam kriteria kuat.

\section{Ucapan terima kasih}

Terima kasih penulis ampaikan kepada Politeknik Medica Farma Husada Mataram, Jurusan Teknologi Laboratorium Medis Politeknik Medica Farma Husada Mataram. Laboratorium Fisiologi dan Bioteknologi Tanaman, Fakultas Pertanian, Universitas Mataram dan Laboratorium Litbangkes RSUP NTB

\section{Referensi}

Atmosukarto, I. \& Anggia P. (2006). Mikroba Endofit: Sumber Molekul Baru yang Berpotensi. BioTrends, 1 (2).

Barik B.P, Tayung K, Jagadev P.N, \& Dutta S.K. (2010). Phylogenetic Placement of an Endophytic Fungus Fusarium oxysporum Isolated from Acorus calamus Rhizomes with Antimicrobial Acticity. EJBS 2(1): 816

Budiprakoso, B. (2010). Pemanfaatan Cendawan Endofit Sebagai Penginduksi. 
Ebtasari. I. A. (2007). Uji Daya Antijamur Perasan dan Rebusan Daun Sirih (Piper betle L.) terhadap

Candidaalbicans Secara In Vitro. Universitas Islam Indonesia, Jogyakarta.

Gemsih, Milda, Djufri, \& Supriatno (2017). "Isolasi dan Identifikasi Jamur Endofit Pada Daun Jamblang (Syzygium Cumini L)." Jurnal Ilmiah Mahasiswa Fakultas Keguruan Dan Ilmu Pendidikan Unsyiah 2(1):78-89.

Hertiani, T \& Indah.P. (2002). Minyak Atsiri Hasil Destilasi Ekstrak Etanol Daun Sirih $(P$. betle) dari beberapa Daerah di Jogyakarta dan Aktifitas Antijamur terhadap Candida albicans. Majalah Farmasi Indonesia.13 (4): 193-199.

Hidayati, N. (2010). Isolasi dan identifikasi jamur endofit pada umbu bawang putih (Allium sativium) sebagai penghasil senyawa antibakteri terhadap bakteri Streptococcus Mutans dan Escherichia coli.Skripsi.Universitas Islam Negeri (UIN)

Ibrahim, A. M. (2013). Uji Efektifitas Ekstrak Daun Sirih Hijau (Piperbetle Linn) terhadap pertumbuhan bakteri streptococcus viridians dengan metode Disc diffusion. Universitas Islam Negeri syarif hidayatullah. Skripsi. Jakarta (http://repository.uinjkt.ac.id/dspace/bitstr eam/123456789/26341/1/Angga\%20Maul ana\%20Ibrahim-fkik.pdf.

Indriana, h. h. (2005). Eksplorasi jamur endofit antagonis terhadap phytophthora spp. Penyebab penyakit busuk pada batang jeruk.Skripsi. Jurusan hama

Iptika A. (2014). Keterkaitan kebiasaan dan kepercayaan mengunyah sirih pinang dengan kesehatan gigi. Jurnal Unair. 3(1): 64-69.

Katili, A. S, et al. (2015). Inventarisasi Tumbuhan Obat dan Kearifan Lokal Masyarakat Etnis Bune dalam Memanfaatkan Tumbuhan Obat di Pinogu, Kabupaten Bonebolango, Provinsi Gorontalo.Pros Sem Nas Masy Biodiv Indon. 1 (1): 78-84.
Katzung BG, Susan BM, Anthony JT. Basic and clinical pharmacology. Ed 12th. California: McGraw-Hill; (2011). Ketahanan Tanaman Padi Terhadap Wereng Cokelat Nilaparvata lugens.Skripsi. Departernen Proteksi Tanaman, Fakultas Pertanian, Institut Pertanian Bogor, Bogor.)

Naglik, J.R., Richardson, J.P., \& Moyes, D.L., (2014). Candida albicans Pathogenicity and Epithelial Immunity, PLOS Pathogens, 10 (8) : p. 1-4

Noverita (2009). Isolasi dan UjiAktivitas Antibakteri Jamur EndofitDari Daun dan Rimpang Zingiberottensi Val. Jurnal Farmasi Indonesia

.Nurrokhman (2006). Efek Rebusan Daun Sirih P/ada Peningkatan Kepekaan Staphylococcus aureus terhadap Ampisilin in vitro. Jurnal Kedokteran Yarsi 14 (1): 024-028.

Nurul Rahmah, \& Aditya Rahman (2010).“Uji Fungistatik Ekstrak Daun Sirih (Piper betle L.) terhadap Candida albicans". Jurnal Bioscientae, 7(2), h.17-24.oral health an overview. J Evolution of Medical and Dental Sciences; 2: 3523-3534.

Saraswati, D. (2011). Pengaruh Konsentrasi Ekstrak Daun Sirih Terhadap Daya Hambat Escherichia Coli. Universitas Negeri Gorontalo. Jurnal Health \& Sport.Gorontalo (http://repository.ung.ac.id/get/karyailmia h/463/Pengaruh-Konsentrasi-EkstrakDaun-Sirih-Terdadap-daya-hambat-Ecoli.pdf.diakses pada02Mei Tahun2017)

Sardi, et al. (2013). Candida species: Current epidemiology, pathogenicity, biofilm formation, natural antifungal products and new therapeutic options. Journal of Medical Microbiology. 62(1).10-24.

Sharma (2009). Evaluation of the antimicrobial, antioxidant, and anti-inflammatory activities of hydroxychavicol for its potential use as an oral care agent.Antimicrob.Agents Chemother.53: 216-222. 
Sinaga, Elfrida. (2009). Isolasi dan Identifikasi

Antifungal Bakteri Endofit dari

Andaliman (Zanthozylum acanthopodium

DC) Terhadap Fungi Perusak

Makanan.Skripsi.Universitas Sumatra

Utara

Sugiyono (2011). Metode penelitian kuantitatif, kualitatif, dan $\mathrm{R}$ \& $\mathrm{D}$. Bandung: AFABETA

Suwandi, U. (1989). Mikroorganisme Penghasil Antibiotik. Pusat Penelitian dan Pengembangan PT. Kalbe Farma. Jakarta.

Tan, R.X.; \& Zou, W.X. (2001). Endophytes: a rich source of functional metabolites. Nat.Prod. Rep. 18: 448-459

Vilca Veronica Hasiani, Islamudin Ahmad, \& Laode Rijai (2015). Isolasi Jamur Endofit dan Produksi Metabolit Sekunder Antioksidan dari Daun Pacar (Lawsonia inermis L.) Laboratorium Penelitian dan Pengembangan Farmaka Tropis Fakultas Farmasi Universitas Mulawarman, Samarinda, Kalimantan Timur

Zahid, F \& Ismi, N. (2015). Rebusan Daun Sirih Dan Kunyit Terhadap Keputihan Patologis Pada Remaja Putri.Journals of Ners Community. Universitas Gresik 